\title{
Effect of biofumigation by Calligonum polygonoides, dry olive leaves, and ash of olive leaves on chilli pepper growth and recovery of Rhizoctonia solani
}

\author{
Ahmed A. AL-HAMMOURI*1, Salman D. AL-KOFAHI ${ }^{1}$, Jwan H. IBBINI ${ }^{1}$, Shereen A. ABUSMIER ${ }^{1}$, Soum \\ SANOGO $^{2}$
}

Received April 16, 2017; accepted March 08, 2018.

Delo je prispelo 16. aprila 2017, sprejeto 08. marca 2018.

\begin{abstract}
Rhizoctonia solani J.G. Kühn is a serious soilborne pathogen in chilli fields worldwide. This study examined the effect of biofumigation using arta (Calligonum polygonoides L.) and olive (Olea europaea L.) plant material on chilli growth and recovery of $R$. solani from chilli plants. The experiment was conducted under greenhouse conditions in potted soil amended with no plant material (control) or with plant material from Calligonum and Olea (olive leaves, or ash of olive leaves). Chilli was planted in the amended soils and inoculated with $R$. solani. Plant height, number of fruits, and frequency of recovery of $R$. solani from chilli were recorded. Soil amendment with Calligonum plant material resulted in the lowest frequency of recovery of $R$. solani. Moreover, Calligonum treatment increased dry mass and height of chilli plants compared to other treatments. Also, treatment with olive plant parts inhibited $R$. solani growth and enhanced growth of chilli compared to the control treatment. Thus, $C$. polygonoides and $O$. europaea are potental biofumigant plants to control $R$. solani.
\end{abstract}

Key words: chilli pepper; Capsicum annuum; ; biofumigation; Calligonum polygonoides; olive; Rhizoctonia solani; inoculation

\section{IZVLEČEK}

\author{
UČINKI BIOFUMIGACIJE Z VRSTO Calligonum \\ polygonoides, SUHIMI LISTI OLJKE IN PEPELOM IZ \\ OLJČNIH LISTOV NA RAST ČILIJEV IN \\ REGENERACIJO GLIVE Rhizoctonia solani
}

Gliva Rhizoctonia solani J.G. Kühn je pomembne talni pathogen na poljih čilijev širom po svetu. V raziskavi je bil preučen učinek biofumigacije $\mathrm{z}$ vrsto dresnovk (Calligonum polygonoides L.) in pripravki iz oljke (Olea europaea L.) na rast čilijev in njihovega uspevanja po inokulaciji $\mathrm{z}$ glivo $R$. solani . Poskus je bil izveden $\mathrm{v}$ rastlinjaku kot lončni poskus, $\mathrm{v}$ katerem prsti niso dodali ničesar (kontrola) ali z dodatkom rastlinskih delov vrst Calligonum in Olea (oljčni listi ali pepel iz njih). Čiliji so bili posajeni v prst z dodatki in inokulirani z glivo $R$. solani. Zabeležena je bila višina rastlin, število plodov in frekvenca okrevanih rastlin po inokulaciji z glivo $R$. solani. Dodatki delov vrste Calligonum $\mathrm{k}$ prsti so rezultirali k najmanjši obnovi glive $R$. solani. Še več, dodatki delov te vrste so povečali višino in suho maso čilijev v primerjavi z drugimi obravnavanji. Tudi obravnavanja s pripravki iz oljke so zavrla rast glive $R$. solani in pospešila rast čilijev $\mathrm{v}$ primerjavi s kontrolo. Pripravki iz vrste $C$. polygonoides in oljke so lahko biofumigacijska sredstva za nadzor talne glive R. solani.

Ključne besede: čili; Capsicum annuum; biofumigacija; Calligonum polygonoides; oljka; Rhizoctonia solani; inokulacija

\footnotetext{
1 Department of Land Management \& Environment, Faculty of Natural Resources \& Environment, Hashemite University (HU), P.O. Box 150459, Zarqa 13115, Jordan, corresponding author: hammouri@ hu.edu.jo

2 Department of Entomology, Plant Pathology, and Weed Science, New Mexico State University, Las Cruces, NM 88003, USA
}

This study was funded by The Deanship of Scientific Research at HU, Zarqa, Jordan. 


\section{INTRODUCTION}

Chilli pepper (Capsicum annиum L.) hereafter referred to as 'chilli', is an important vegetable crop worldwide (Castillo et al., 2009; Scholberg et al., 2009). It is grown for several purposes such as fresh market, processing, extraction of food coloring, pharmaceuticals, and other products (Goldberg, 2001). Chilli yield has declined clearly during the last decade for a variety of reasons (Sanogo and Carpenter, 2006). Soilborne pathogens belonging to genera Phytophthora, Verticillium, Fusarium, and Rhizoctonia significantly reduced yield and quality of chilli (Sultana et al., 2008; Tariq et al., 2009). Plant pathogens such as $R$. solani J.G. Kühn are of great importance since they can attack plants throughout the cropping cycle, causing death of young seedlings early in the season and root rot in mature plants in the mid to late season (Woodhall et al., 2007).

Complete control of $R$. solani is not possible, but the activities of the pathogen can be minimized (Abeysinghe, 2009). Application of certain chemical fungicides could be the best solution to reduce the problems caused by $R$. solani and other soilborne plant pathogens (Bubici et al., 2006; Cimen et al., 2004; Jarvis, 1993). However, fungicides are not the most effective way to manage this pathogen. Moreover, fungicides has negative impact on the environment (Lazarovits et al., 2008; Powelson and Rowe, 1993). Therefore, environmental friendly control methods, such as biofumigation, are highly recommended and increasingly being used.

Biofumigation depends on the breakdown of plant metabolites in soil to produce volatile compounds that can suppress plant pathogens, nematodes, and weeds (Larkin et al., 2011). Many crops have been proven to work as natural biofumigants against several soilborne pests. Those plants can release glucosinolates and isothiocyanates through soil and inhibit soilborne pathogens (Aires et al., 2009; Kirkegaard et al., 2000; Laegdsmand et al., 2007; Matthiessen and Kirkegaard, 2006). Examples of biofumigant plants are Brassica carinata A. Braun (Porras et al., 2009; Snapp et al., 2007), B. oleracea L. (Fan et al., 2008), and B. napus L. (Laegdsmand et al., 2007). Those plants were intensively studied as biofumigants worldwide.

Other plants might have the potential to act as biofumigants and are still undiscovered and require intensive research work. Examples include Calligonum spp. and O. europaea L.. The Calligonum genus descended from the Polygonaceae plant family and it is known as "arta" (Abrahim et al., 2014). Around 80 species across the Mediterranean region, Asia and North
America belong to the Calligonum genus (Halis, 2007). Most Calligonum plants are shrubs with diffuse and irregular woody branches. These plants have scale-like or filiform simple leaves with perfect flowers having 10-18 stamens with filaments connate at the base. Among Calligonum species is C. polygonoides L., which is a small shrub, usually $10 \mathrm{~cm}$ to $15 \mathrm{~cm}$ high, but occasionally may reach $25 \mathrm{~cm}$ in height with a girth of 2.5 to $5 \mathrm{~cm}$ (Kaul, 1963). Calligonum contains several chemicals which encouraged researchers to investigate the potential of these plants for medical uses (Kamil et al., 2000). Examples of chemicals found in Calligonum plants include anthraquinones, flanovonids, and dehydrodicatechin (Farid et al., 2007; Ghazanfar 1994; Kamil et al., 2000). Anthraquinones found in Calligonum showed high antimicrobial potential (Alkhalifah, 2013; Zaki et al. 1984). Similarly, these plants might have some components that have potential to control certain oilborne plant pathogens. Also, it was found that Calligonum plant material inhibit growth of two plant fungal pathogens, Alternaria spp. and Rhizopus spp. (Abrahim et al., 2014).

Another promising biofumigant plant is O. europea. Olive leaves were studied widely for their extracts and for their medicinal properties and uses (BenaventeGarcia et al., 2000). Extracts from olive-mill wastes, for example, include organic matter, potassium, carbohydrates, fats, polyphenols, and polyalcohols (Romero et al., 2005). Our interest in olive leaves is based on bioassays that showed antifungal effect of olive leaves against some human pathogens at laboratory level (Pinelli et al., 2000). Moreover, production of olive oil becomes a very common industry (Nogales et al., 2006), and a huge number of olive trees are growing worldwide. Consequently, huge amounts of olive leaves are lost during pruning and harvesting of olive fruit as waste. Traditionally, many farmers used to burn the pruned twigs with leaves and the resulting ash is incorporated with soil. Also, olive waste ash was used as soil amendment (Nogales et al., 2006). However, little research, if any, had focused on the effect of fresh olive leaves or leaf ash on soilborne plant pathogens. Therefore, our long-term goals are to encourage farmers and agricultural practioners to use the widely available plants as biofumigants to inhibit soilborne pathogens and consequently minimize the use of chemicals in the agroecosystem. Our objectives were to study the effect of incorporating $C$. polygonoides above-ground plant parts, olive leaves or olive ash (leaves and twigs ash) into soil on the recovery of $R$. solani from roots of chilli plants and on dry mass, number of fruits, and plant height of chilli pepper. 


\section{MATERIALS AND METHODS}

\subsection{Inoculum preparation}

The $R$. solani isolate used was recovered from infected tomato plants displaying typical symptoms of Rhizoctonia root rot. The isolate was grown on potato dextrose agar in petri plates.

\subsection{Soils}

A large composite sample of silty clay soil (calcareous), was collected from the top $15 \mathrm{~cm}$ of a field at the Hashemite University, Zarqa, Jordan. The soil was thoroughly mixed, and stored until use. Round plastic pots $(10 \mathrm{~cm}$ upper radius, $7.5 \mathrm{~cm}$ lower radius, and depth of $18 \mathrm{~cm}$ ) were used. Three openings at the bottom of each pot were made for drainage. The pots were filled with soil $(4 \mathrm{~kg})$ mixed with each type of biofumigant plant materials. The pots were irrigated with tap water as needed throughout the study period.

\subsection{Biofumigant plant materials}

The aboveground Calligonum parts were collected from fields near the Hashemite University during summer 2014. Plant parts were spread over sheets of cheesecloth and allowed to air dry at room temperature $\left(20-25^{\circ} \mathrm{C}\right)$. Then, dry plant materials were milled and homogenized with a plant grinder (MF 10 basic-Thomas No. 1203C62), and collected and stored in plastic bags until use. By the time of olive fruit harvesting (October 2014), olive twigs were collected from local olive orchards at the Hashemite University. Leaf blades and peduncles were removed from the collected twigs, dried at room temperature for two weeks, and grinded. Olive twigs and leaves were collected at the time of pruning. Then, they were burned and their ash was collected and stored in plastic bags until use.

\subsection{Pot preparation and plant production}

On March 2015 and 2016 in experiments 1 and 2, soil of each pot was mixed thoroughly with $150 \mathrm{ml}$ of the grinded plant materials according to each treatment (Calligonum, olive leaves, and olive ash). No plant materials were added to pots in the control treatment. One chilli seedling ('AZ20') at the six to eight leaf growth stage was transplanted into each pot at a depth of $10 \mathrm{~cm}$. The chilli seedlings were grown in germination trays containing a mixture of peat moss and perlite (1:1volume basis). The pots were irrigated immediately after transplanting and maintained in the greenhouse with a minimum air temperature of $20{ }^{\circ} \mathrm{C}$ and maximum air temperature of $32{ }^{\circ} \mathrm{C}$ (average greenhouse air temperature was $25^{\circ} \mathrm{C}$ ).

\subsection{Inoculation}

Shortly before inoculation, two holes were made to a depth of $2.5 \mathrm{~cm}$ and approximately $1 \mathrm{~cm}$ away from the seedling. On April 2015 and 2016, pots were inoculated simultaneously for each experiment. Seedlings in both experiments were at the 6-8 leaf growth stage. All pots were inoculated by placing one mycelium plug, $1 \mathrm{~cm}$ in diameter, of $R$. solani colony grown on potato dextrose agar into each hole. All holes were filled with soil after inoculation and the pots were irriagated with tap water.

\subsection{Rhizoctonia solani assessment}

Three and a half months after inoculation tap roots were collected and stored in a refrigerator until plating. Each tap root was cut into top, middle and bottom parts. The middle part of the tap root was then clipped into eight homogeneous segments under aseptic conditions, and four segments were plated on a $9 \mathrm{~cm}$ diameter petri plate containing potato dextrose agar. Two petri dishes were assigned to each treatment. All plates were then incubated at room temperature $\left(22\right.$ to $\left.25{ }^{\circ} \mathrm{C}\right)$. Two weeks after incubation, colonies of $R$. solani were counted to estimate the $R$. solani frequency based on 8 tap root segments.

\subsection{Experimental design and data analysis}

Each experiment was conducted in a randomized completly block design with four replicates per each of the four treatments: control, Calligonum, olive leaves, and olive ash. The measured variables were: (i) $R$. solani frequency of recovery from tap root segments, (ii) dry mass of the above-ground plant parts, (iii) plant height, (iv) and number of fruits. All data were subjected to an analysis of variance (ANOVA) using the Proc GLM procedure in SAS version 9.2 (SAS institute, Cary, NC). Proc GLM was used to calculate F statistics for the overall treatment effect. Least significant difference (LSD) was used to carry out pairwise comparisons to separate treatment means. All statistical tests were assessed at $5 \%$ significance level. 


\section{RESULTS AND DISCUSSION}

\subsection{Rhizoctonia solani assessment}

The overall $\mathrm{F}$ test for both expeiments $(P<0.0001$ in experiment 1 and $P=0.002$ in experiment 2) implies that the frequency of $R$. solani recovered from chilli tap root segments was significantly lower when soil was mixed with plant materials than that in control treatment (Fig. $1 \& 2$ ).

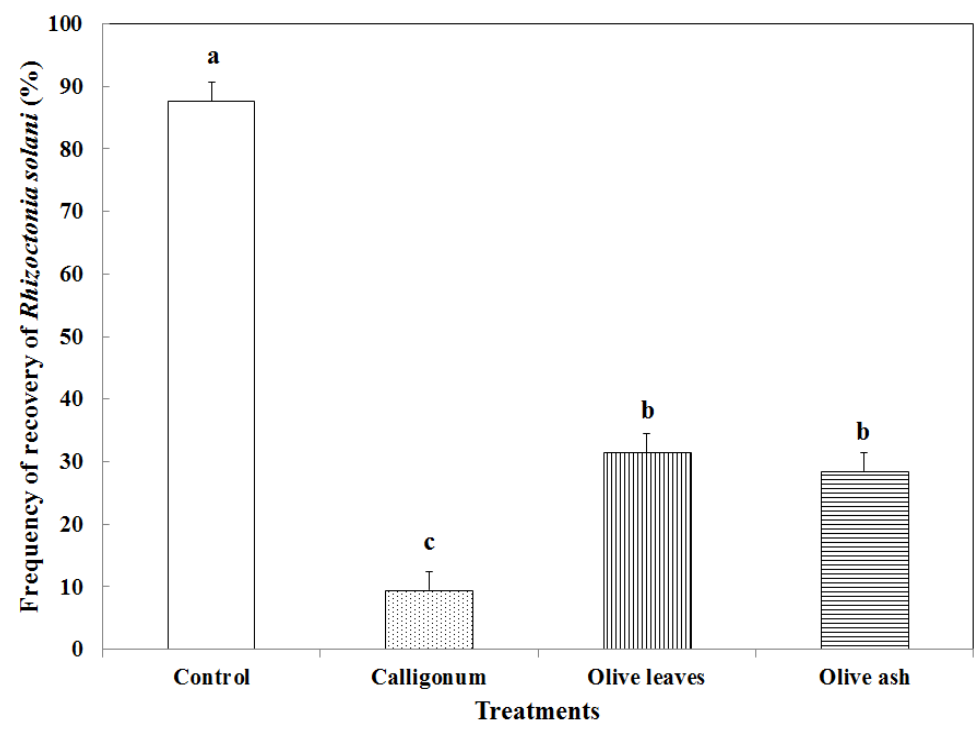

Figure 1: Frequency of recovery of Rhizoctonia solani from tap root segments of chilli in experiment 1. Each number is the mean of four individual plants, comprised of four replicates per treatment. Bars with the same letter are not significantly different based on the LSD at $5 \%$ level of significance.

In experiment 1 , the frequency of $R$. solani from root segments was significantly the lowest in the Calligonum treatment compared to all other treatments (Fig. 1). While in experiment 2 (Fig. 2), olive ash treatment resulted in the lowest frequency of $R$. solani compared to other treatments. Thus, mixing soil with Calligonum, olive leaves, and olive leaves ash reduced $R$. solani recovery from tap roots significantly.

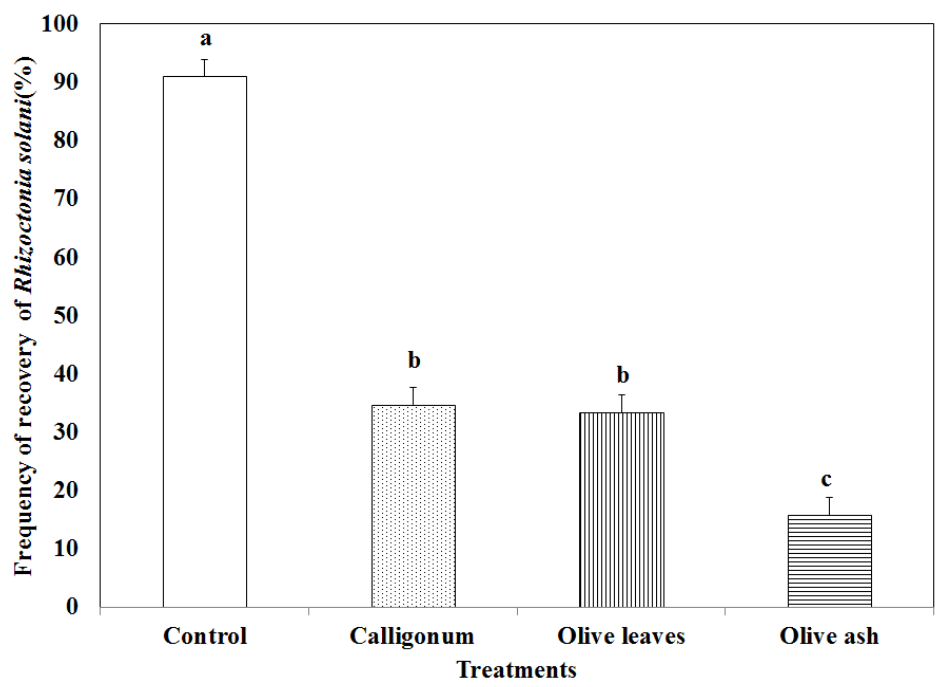

Figure 2: Frequency of recovery of Rhizoctonia solani from tap root segments of chilli in experiment 2. Each number is the mean of four individual plants, comprised of four replicates per treatment. Bars with the same letter are not significantly different based on the LSD at $5 \%$ level of significance. 


\subsection{Plant growth}

In experiment 1 and $2(P=0.002)$, dry mass was significantly higher for plants grown in soil mixed with
Calligonum than plants grown in soil under all other treatments (Fig. $3 \& 4$ ).

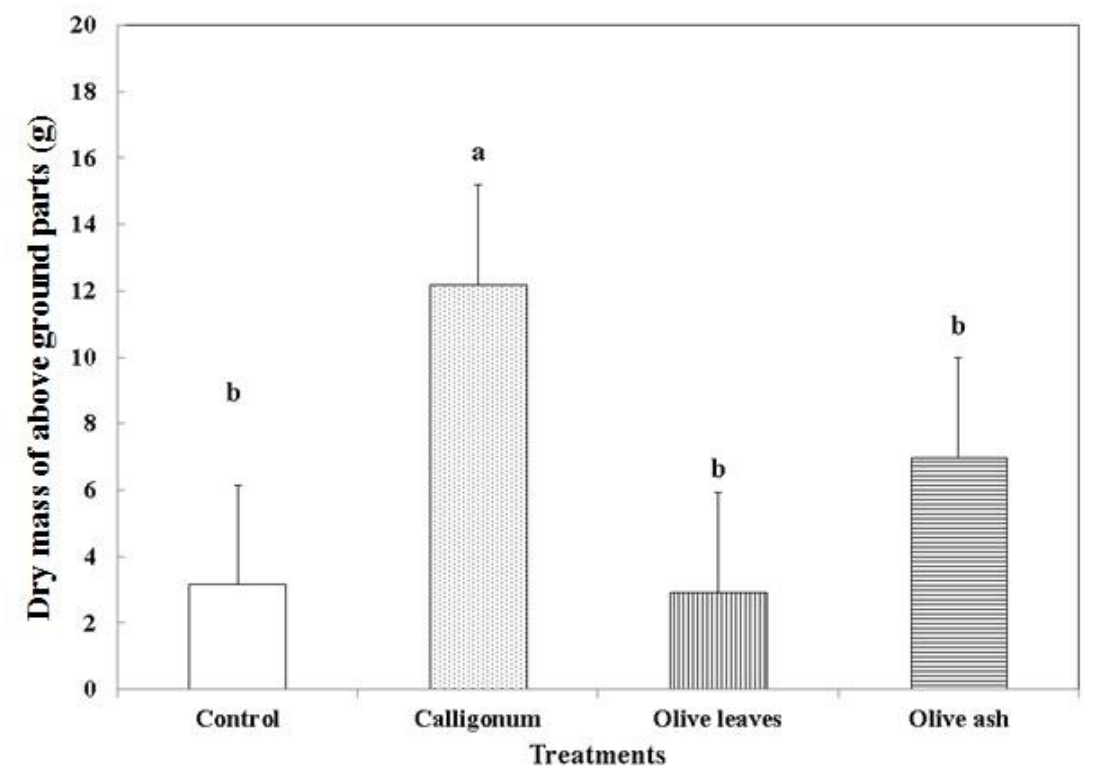

Figure 3: Dry mass of aboveground parts of chile in experiment 1. Each number is the mean of four individual plants, comprised of four replicates per treatment. Same letters on bars of the same parameter are not significantly different based on the LSD at $5 \%$ level of significance

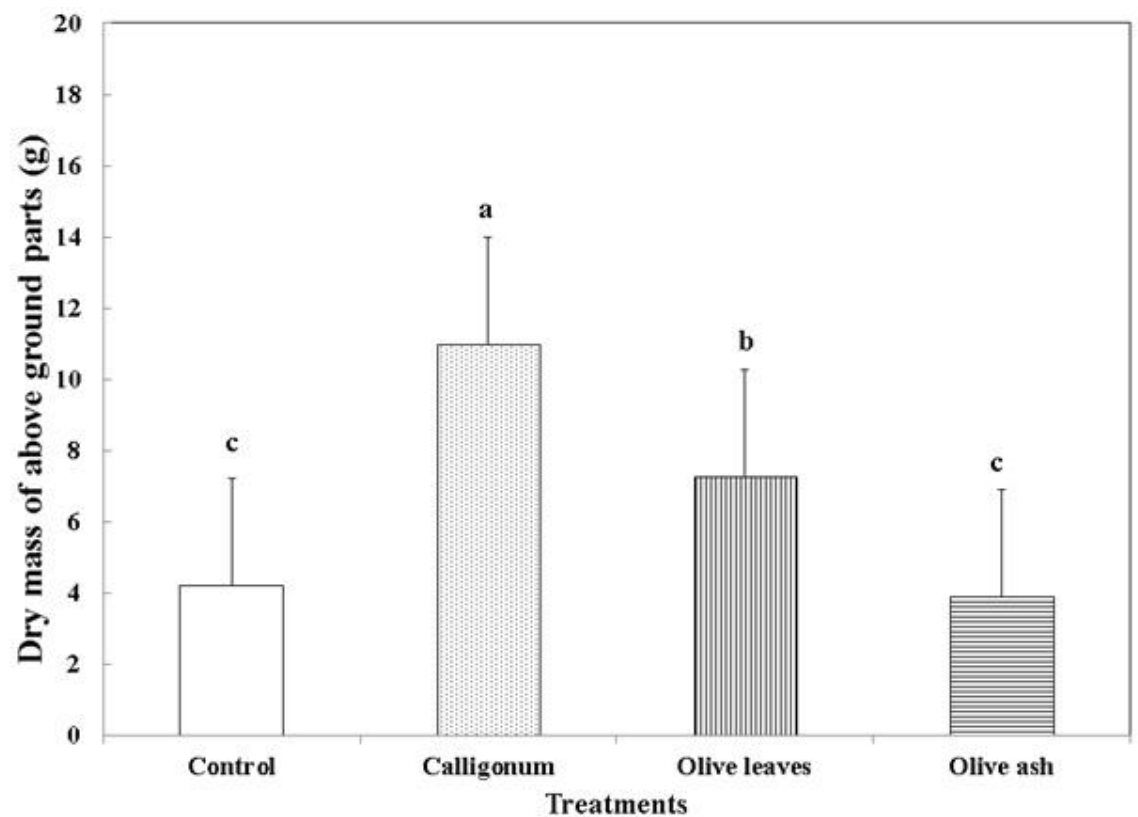

Figure 4: Dry mass of aboveground parts of chilli in experiment 2. Each number is the mean of four individual plants, comprised of four replicates per treatment. Bars with the same letter are not significantly different based on the LSD at $5 \%$ level of significance. 
In experiment 2 , the dry mass of the above-ground parts of the chilli plants grown in soil mixed with olive leaves was significantly $(P=0.0035)$ higher than that of plants grown in soil mixed with olive ash. On the other hand, plant height was significantly different among treatments in experiment 1 (Fig. 5).

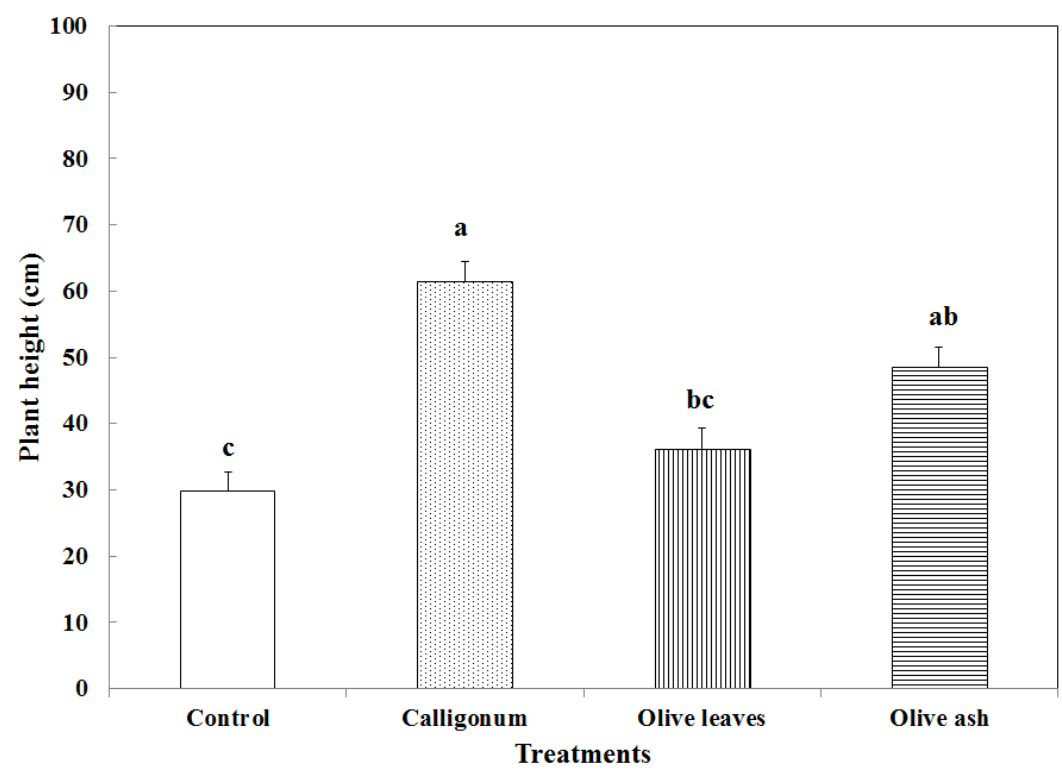

Figure 5: Plant height $(\mathrm{cm})$ in experiment 1. Each number is the mean of four individual plants, comprised of four replicates per treatment. Bars with the same letters are not significantly different based on the LSD at $5 \%$ level of significance

Plants grown in soil mixed with Calligonum or olive ash were significantly $(P=0.025)$ taller than plants grown in soil mixed with olive leaves or control soil. However, there were no significant differences among plants height under all treatments of experiment 2 (data not shown). Similarly, all comparisons indicated no significant effect of biofumigant plant materials on the number of chile fruits in both experiments.

Under field conditions, chilli plants are exposed to numerous soilborne pathogens such as $R$. solani (Skaggs et al., 2000; Sanogo, 2003). Rhizoctonia solani is well known as a potent pathogen that causes huge losses in yield of many crops (Siddiqui and Shaukat, 2005). Controlling soilborne fungal pathogens was achieved by several methods including the use of chemicals. On the other hand, alternative methods including biofumigation have been used. In this experiment, locally available plant residues were used. Calligonum and olive plant parts showed significant reduction in the frequency of $R$. solani recovered from tap roots of chile plants. Chilli was selected as an indicator crop since it is widely grown worldwide and has a great value .Calligonum plant material inhibited $R$. solani in both experiments significantly (Fig. $1 \& 2$ ). Incorporation of grinded Calligonum aboveground plant parts into soil was effective in reducing the recovery of $R$. solani from chilli tap roots. This result provides an evidence that
Calligonum contains substances that are able to inhibit $R$. solani. In agreement with this evidence, Abrahim et al. (2014) concluded that Calligonum species have antifungal compounds effective in the treatment of plant diseases. Different factors might have affected the efficiency of $R$. solani recovery and chilli responses. These factors include the inoculum level of $R$. solani which was two mycelium plugs, diameter of $1 \mathrm{~cm}$, of the colony grown on potato dextrose agar, and the amount, and timing and method of application of Calligonum. On the other hand, Calligonum plant material gave the highest dry mass of chilli aboveground parts (Fig. $3 \& 4$ ). It is possible that Calligonum plant material enhanced chilli crop to uptake water and nutrients since it inhibited growth of $R$. solani. Additionally, the use of Calligonum encouraged chilli roots growth which possibly had lead to better performance of chilli plants. Calligonum treatments produced the tallest chilli plants (Fig. 5). This could be attributed to the inhibition of $R$. solani, thus allowing chilli plant to grow well.

Similarly, olive leaves used as dry material or ash showed significant reduction in the frequency of $R$. solani from chilli tap roots. Plants grown in soil amended with olive plant material showed comparable increase in dry mass and plant height. The grinded, burned, or decomposed plant parts used in these 
experiments might have also contributed to the growth and development rate of chilli not only as inhibitors of $R$. solani, but also as a source of nutrients. In agreement with our results, Solomon et al. (2015) concluded that olive leaves incorporated into soil increased soil fertility and increased plant growth. Similarly, it was found that olive waste ash increased dry mass of chilli stems and leaves significantly (Nogales et al., 2006). Also, it was found that adding dry olive-mill wastes to the soil increases phophorus and potassium contents of chilli leaves (Benitez et al., 2000). Furthermore, olive leaves contain many substances reported to have inhibitory effects on several fungi. It is assumed that $R$. solani was inhibited in our experiments because of the effects of such substances.

The primary active compounds in the raw olive leaves include oleuropein and hydroxytyrosol, as well as several other polyphenols and flavonoids such as oleocanthal and elenolic acid (Vivioli et al., 1998). It is also expected that plant materials added to the soil in our experiments encouraged microbial activity in the rhizosphere of chilli. Consequently, beneficial soil microorganisms could compete with $R$. solani and reduce the activities of this pathogen. Benitez et al. (2000) suggested that olive plant material increased microbial number and activity in chilli rhizosphere. Our results showed promising results of using olive leaves, dry or ash, to control $R$. solani. Additional research is needed in order to explore more aspects of using biofumigant plants to inhibit soilborne pathogen in major crops. Our current study may be the first research to investigate the use of Calligonum, olive leaves, and ash of olive leaves as biofumigants to control $R$. solani on chilli crop.

\section{CONCLUSION}

We showed that incorporating $C$. polygonoides, olive leaves, and ash of olive leaves in soil infested by $R$. solani is effective in reducing the frequency of recovery of the pathogen from chilli, and in increasing dry mass of chilli aboveground plant parts. The incorportated plant materials can also serve as a source of nutrients to support plant health and plant growth. Future work should be conducted with focus on the relationship between plant growth and plant health and the amount, and timing and method of application of the biofumigants, and inoculum levels of $R$. solani.

\section{REFERENCES}

Abeysinghe, S. (2009). Effect of combined use of Bacillus subtilis CA32 and Trichoderma harzianum RU01 on biological control or Rhizoctonia solani on Solanum melongena and Capsicum annuum. Plant Pathology Journal, 8, 9-16. https://doi.org/10.3923/ppj.2009.9.16

Abrahim, J., Afrah, E., M., Mudawi, M., E. (2014). Assessment of in-vitro anti-fungal potential of ethanolic extract of Calligonum comosum against two fungal postharvest pathogens of fruit and vegetables in Saudi Arabia. International Journal of Applied Biology and Pharmaceutical Technology (ijabpt), 5,90-94.

Aires, A., Carvalho, R., Barbosa, M. D. C., Rosa, E. (2009). Suppressing potato cyst nematode, Globodera rostochiensis, with extracts of Brassicacea plants. American Journal of Potato Research, 86, 327-333. https://doi.org/10.1007/s12230-009-9086-y

Alkhalifah, DHM, (2013). In-vitro antibacterial activity of ethanol extract of Calligonum comosum plant against four human pathogens in Saudi Arabia.
International Journal of Plant, Animal and Environmental Sciences, 3, 170 -175.

Benavente-Garcia, O., Castillo, J., Lorente, J., Ortuno, A., Del Rio, J. (2000). Antioxidant activity of phenolics extracted from Olea europa L. leaves. Food Chemistry, 68, 457-462. https://doi.org/10.1016/S0308-8146(99)00221-6

Benitez, E; Melgar, R; Sainz, H; Gomez, M; Nogales, R. (2000). Enzyme activities in the rhizosphere of pepper (Capsicum annuum, L.) grown with olive cake mulches. Soil Biology \& Biochemistry, 13(32), 1829-1835. https://doi.org/10.1016/S00380717(00)00156-5

Bubici, G., Amenduni, M., Colella, C., D’Amico, M., Cirulli, M. (2006). Efficacy of acibenzolar-Smethyl and two strobilurins, azoxystrobin and trifloxystrobin, for the control of corky root of tomato and Verticillium wilt of eggplant. Crop Protection, 25, 814-820. https://doi.org/10.1016/j.cropro.2005.06.008

Castillo, C. R., Sotomayor, L. S., Ortiz, C. O., Leonelli, G. C., Borie, F. B., Rubio, R. H. (2009). Effect of arbuscular mycorrhizal fungi on an ecological crop 
of chile peppers (Capsicum annuum L.). Chilean Journal of Agricultural Research, 69, 79-87. https://doi.org/10.4067/S0718-58392009000100010

Cimen, I., Basbag, S., Temiz, M., Sagir, A. (2004). The effect of paclobutrazol, growth retardant, on cotton growth and Verticillium wilt (Verticillium dahliae Kleb.). Plant Pathology Journal, 3, 35-39. https://doi.org/10.3923/ppj.2004.35.39

Fan, C. M., Isong, G. R., Qi, P., Ji, G. H., He, Y. Q. (2008). Potential biofumigation effects of Brassica oleracea var. caulorapa on growth of fungi. Journal of Phytopathology, 156, 321-325. https://doi.org/10.1111/j.1439-0434.2007.01343.x

Farid, A. B., Madiha, A., Mohamed, R. A. (2007). Evaluation of cytotoxic compounds from Calligonum comosum L. growing in Egypt. Zeitschrift für Naturforschung, 62, 656- 660.

Ghazanfar, S. A. (1994). Handbook of Arabian Medicinal Plants. CRC Press, p.173.

Goldberg, N. P. (2001). Chilli pepper diseases. New Mexico State University, Colleg of Agricultural, Consumer and Environmental Sciences. Circular $549 . \quad$ Online publication. http://aces.nmsu.edu/pubs/_circulars/circ549.html. 6/27/2010.

Halis Y, Ed. (2007). Plant Encyclopedia in area Oued Souf: desert plants common in the Big East race, El Walid: 62-63.

Jarvis, W. R. (1993). Managing diseases in greenhouse crops. American Phytopathological Society Press. St Paul, MN.

Kamil M, Jayaraj AF, Ahmad F, Gunasekhar C, Samuel S, Habiballah M, Chan K, (2000). Pharmacognostic andphytochemical standardisation of Calligonum comosum. Journal of Pharmacy and Pharmacology, 52 (Suppl), 262 p.

Kaul, R. N. (1963). Need for afforestation in the arid zones of India. La-Yaaran, 13.

Kirkegaard, J. A., Sarwar, M., Wong, P. T. W., Mead, A., Howe, G., Newell, M. (2000). Field studies on the biofumigation of take-all by Brassica break crops. Australian Journal of Agricultural Research, 51, 445-456. https://doi.org/10.1071/AR99106

Laegdsmand, M., Gimsing, A. L., Strobel, B. W., Sǿrensen, J. C., Jacobsen, O. H., Christian, H., Hansen, B. (2007). Leaching of isothiocyanates through intact soil following simulated biofumigation. Plant Soil, 291, 81-92. https://doi.org/10.1007/s11104-006-9176-2

Larkin, R. P., Griffin, T. S. (2007). Control of soilborne potato diseases using Brassica green manures. Crop
Protection, 26, 1067-1077. https://doi.org/10.1016/j.cropro.2006.10.004

Lazarovits, G., Conn, K. L., Abbasi, P. A., Soltani, N., Kelly, W., McMillan, E., Peters, R. D., Drake, K. A. (2008). Reduction of potato tuber diseases with organic soil amendments in two Prince Edward Island fields. Canadian Journal of Plant Patholology, 30, 37-45. https://doi.org/10.1080/07060660809507494

Matthiessen, J. N., Kirkegaard, J. A. (2006). Biofumigation and enhanced biodegradation: opportunity and challenge in soilborne pest and disease management. Critical Reviews in Plant Sciences, 25, 235-265. https://doi.org/10.1080/07352680600611543

Nogales, R., Melgar, Benetiz, E. (2006). Potential use of olive-waste ash from congeneration plants as a soil amendment. Journal of Environmental Science and Health Part B, 41, 1405-1415. https://doi.org/10.1080/03601230600964282

Pinelli, P., Galardi, C., Mulinacci, N., Vincieri, F., Tattini, ., Romani, A .(2000). Quali-quantitative analysis and antioxidant activity of different polyphenolic extracts from Olea europea L. leaves. Journal of Commodity Science, 39(2), 71-83.

Porras, M., Barrau, C., Romero, E., Zurera, C., Romero, F. (2009). Effect of biofumigation with Brassica carinata and soil solarization on Phytophthora spp. and strawberry. Yield. Proc. VIth Internat. Strawberry Symposium; Huelva, Spain, March 3-7, 2008. Acta Horticulturae, 842, 969-972. https://doi.org/10.17660/ActaHortic.2009.842.215

Powelson, M. L., Rowe, R. C. (1993). Biology and management of early dying of potatoes. Annual Review of Phytopathology, 31, 111-126. https://doi.org/10.1146/annurev.py.31.090193.0005 51

Romero, E.; Benitez, E.; Nogales, R. (2005). Suitability of wastes from olive-oil industry for initial reclamation of a $\mathrm{Pb} / \mathrm{Zn}$ mine tailing. Water, Air, \& Soil Pollution, 165, 153-165. https://doi.org/10.1007/s11270-005-4638-3

Sanogo, S. (2003). Chile pepper and the threat of wilt diseases. Plant Health Progress. https://doi.org/10.1094/PHP-2003-0430-01-RV

Sanogo, S., Carpenter, J. (2006). Incidence of Phytophthora blight and Verticillium wilt within chilli pepper fields in New Mexico. Plant Diseases, 90, 291-296. https://doi.org/10.1094/PD-90-0291

Scholberg, J. M., Zotarelli, L., Tubbs, R. S., Dukes, M. D., Muñoz-Carpena, R. (2009). Nitrogen uptake efficiency and growth of bell pepper in relation to 
Effect of biofumigation by Calligonum polygonoides, dry olive leaves, ... growth and recovery of Rhizoctonia solani

time of exposure to fertilizer solution. Communications in Soil Science and Plant Analysis, 40, 2111-2131. https://doi.org/10.1080/00103620902960625

Siddiqui, I. A., Shaukat, S. S. (2005). Phenylacetic acidproducing Rhizoctonia solani represses the biosynthesis of nematicidal compounds in vitro and influences biocontrol of Meloidogyne incognita in tomato by Pseudomonas fluorescens strain CHA0 and its GM derivatives. Journal of Applied Microbiology, 98, 43-55. https://doi.org/10.1111/j.1365-2672.2004.02457.x

Skaggs, R., Decker, M., VanLeeuwen, D. (2000). A survey of southern New Mexico chilli producers: Production practices and problems. NM Agricultural Experiment Station Technology Bulletin., 782.

Snapp, S. S., Date, K. U., Kirk, W., O'Neil, K., Kermen, A., Bird, G. (2007). Root, shoot tissues of Brassica juncea and cereal secale promote potato health. Plant Soil, 294, 55-72. https://doi.org/10.1007/s11104-007-9228-2

Solomon, T. E., Lodolini, E. M., Neri, D. (2015). Effects of olive shoot residues on shoot and root growth of potted olive plantlets. Scientia Horticulturae, 182, 31-40. https://doi.org/10.1016/j.scienta.2014.11.008
Sultana, V., Ara, J., Ehteshamul-Haque, S. (2008). Suppression of root rotting fungi and root knot nematode of chile by seaweed and Pseudomonas aeruginosa. Journal of Phytopathology, 156, 390359. 0434.2007.01369.x https://doi.org/10.1111/j.1439-

Tariq, S., Khan, R., Sultana, V., Ara, J., EhteshamulHaque, S. (2009). Utilization of endo-root fluorescent Pseudomonas of chilli for the management of root diseases of chilli. Pakistan Journal of Botany, 41, 3191-3198.

Vivioli, F., Bellomo, G. Galli, C. (1998). Free radicalscavenging properties of olive oil polyphenols. Biochemical and Biophysical Research Communications, 247, 60-64. https://doi.org/10.1006/bbrc.1998.8735

Woodhall, J. W., Lees, A. K., Edwards, S. G., Jenkinson, P. (2007). Characterization of Rhizoctonia solani from potato in Great Britain. Plant Pathology, 56, 286-295. https://doi.org/10.1111/j.1365-3059.2006.01545.x

Zaki, D., Abd-El-Aziz, M., El-Gengeihy, S., Morsi, N. (1984). Antimicrobial potentialities of some Egyptian desert plants. Herba Hungarica, 23, 73 84. 